ROCZNIK

TEOLOGII

KATOLICKIEJ

Tom VI

Rok 2007

\title{
Zdzisława Kobylińska
}

Uniwersytet Olsztyński

\section{WYCHOWANIE MORALNE W KULTURZE POKUS}

\section{MORAL EDUCATION IN THE CULTURE OF TEMPTATIONS}

The question of moral education becomes particularly significant in the era of postmodernism. The traditional set of values, cultural and social conventions, the Decalogue, God's law and immutable moral rules are often perceived as an unnecessary burden for the moral development, a burden that can only be taken up at discretion, and is never seen as a permanent factor and a necessary point of reference for educational efforts. The author discusses the dangers and temptations which occur for education. She concludes that the culture of temptations, dominant in the post-modern reality, is slowly moving from the phase of encouragement to the phase of realization, leading to an educational nihilism, an axiological vacuum, and a moral desert.

Zagadnienie wychowania moralnego na tle epoki postmodernizmu nabiera szczególnego znaczenia․ Tradycyjny zespół wartości, wzorce kulturowe, obyczajowe, Dekalog, prawo Boże, niezmienne zasady moralne bywają często traktowane jako niepotrzebny balast, obciążający formację moralną, który może być brany pod uwagę $\mathrm{w}$ procesie wychowawczym jedynie uznaniowo, a nigdy jako stały czynnik i konieczne źródło odniesień pedagogiczno-wychowawczych. Dzieje się tak dlatego, że współczesny świat w imię pluralizmu wartości, różnorakich porządków religijnych, rozmaitych koncepcji antropologiczno-etycz-

Z tej przyczyny powstało wiele wartościowych pozycji, które analizują tę problematykę, jak np. J. Tarnowski, Jak wychowywać?, Warszawa 1993; Wychowywać charakter (materialy III Ogólnopolskiej Konferencji Nauczycieli i Wychowawców), Lublin 2005; M. Dziewiecki, Kochać i wymagać, Kraków 2006; tenże, Wychowanie w dobie ponowoczesności, Kielce 2002; tenże, Osoba i wychowanie, Kraków 2003; tenże, Komunikacja wychowawcza, Kraków 2004; Wychowanie personalistyczne. Wybór tekstów, red. F. Sawicki, Kraków 2005. 
nych, daje absolutną wolność wyboru czegokolwiek, nawet antywartości, aby tylko stało się zadość liberalizmowi wychowawczemu, urastającemu do rangi wartości samej w sobie. Pluralizm, który niewątpliwie może być uważany za przymiot $\mathrm{w}$ tworzeniu kultury i cywilizacji, a zarazem jest nieunikniony w dzisiejszym kontekście otaczającego nas świata, w istocie jednak jest błędnie rozumiany, gdyż utożsamiany bywa $z$ istnieniem i nieskrępowanym wyborem jakiegokolwiek, choćby najbardziej absurdalnego rozwiązania wychowawczego. Tymczasem współczesna kultura, którą nazywam kulturą pokus, jak nigdy dotąd oferuje cały szereg rozwiązań konkretnych problemów wychowawczych, których rozstrzygnięcie nie jest niczym innym jak właśnie uleganiem rozmaitym pokusom, łatwym, tanim i hedonistycznym propozycjom, jakie niesie ze sobą postmodernistyczna koncepcja świata ${ }^{2}$.

Wizja ta w węzłowych punktach sprowadza się przede wszystkim do absolutyzacji wolności jednostki, bez względu na to ile ona ma lat. Wolność widziana jest jako niczym nieskrępowane działanie, nawet jeśli nie ma ono zdefiniowanego celu i nie jest niczym umotywowane. Wychowanie ma więc proponować absolutny luz, nieposkromiony żadnymi ograniczeniami natury moralnej, obyczajowej czy religijnej. Praktycznie przejawia się on w podejmowaniu przez wychowanków rozmaitych aktywności, które nie są adekwatne ani do ich wieku, ani możliwości, ani do odpowiedzialności. Przykładem jest choćby coraz bardziej zaniżony wiek podejmowania inicjacji seksualnych, a także liczba nieplanowanych ciąż. Postulat wolności jednak każe nie zakazywać tych praktyk, a jedynie „zabezpieczać się” przed ich niepożądanymi konsekwencjami. Stąd płyną pomysły rozdawnictwa antykoncepcyjnych środków barierowych, pigułek „dzień po”, a nawet możliwości abortowania ciąż u młodych dziewcząt, bez wiedzy i zgody ich rodziców czy opiekunów. Wychowanie ma być nastawione nie na wpajanie podstawowych cnót umiarkowania, czystości, wstrzemięźliwości i skromności, lecz ma stać się wpajaniem sprytu w osiąganiu maksimum przyjemności, przy jednoczesnym braku ponoszenia odpowiedzialności za ich skutki. Argumentem najczęściej wysuwanym przy okazji usprawiedliwiania tych postaw jest obrona integralnego rozwoju osobowości, także w aspekcie korzystania z nieograniczonej seksualności, traktowanie sfery seksu jako źródła przyjemnych doznań cielesnych, które są zawsze dozwolone, jeśli tylko nie kończą się „kłopotliwymi” konsekwencjami ${ }^{3}$.

Podobna argumentacja pojawia się także w kontekście propagowania i zachęcania do odkrywania w sobie różnych orientacji seksualnych, z których każda

2 Szerzej na temat postmodernistycznej wizji świata por. Z. Sareło, Postmodernizm w pigutce, Poznań 1998; czy też pozycja: Moralność i etyka w ponowoczesności, red. Z. Sareło, Warszawa 1996.

Temat ten, jak i szereg innych szczegółowych zagadnień porusza interesująca praca Marka Czachorowskiego: M. Czachorowski, Nowy imperializm, czyli o tzw. edukacji seksualnej, Warszawa 1997. 
jest dobra i każda godna akceptacji. Warto więc i wolno próbować odkrywać w sobie, być może nieuświadomiony, pociąg seksualny do tej samej płci, wedle zasady: każda orientacja jest równie dobra i warta praktycznego wyrażenia. Co więcej, próba oceny, a jeszcze gorzej, krytyki na przykład aktywnego homoseksualizmu czy biseksualizmu, nazywana jest nietolerancją, ciasnotą intelektualną i zacofaniem, a brak zgody na promowanie postaw homoseksualnych w szkole, określane bywa zamachem na... demokrację i ograniczeniem praw mniejszości. W wielu krajach owa poprawność polityczna w tym kontekście, przejawia się także koniecznością rezygnacji w placówkach publicznych $\mathrm{z}$ używania słów "matka” i „ojciec”, zastępując je słowami „rodzic A” i „rodzic B” lub co najwyżej terminem „opiekunowie” po to, aby nie razić uczuć osób homoseksualnych, pragnących mieć dzieci. Podobnie z rozmaitych podręczników ma zniknąć tylko jeden model rodziny, złożony z matki, ojca i dzieci, a powinien pojawić się alternatywny, złożony np. z dzieci i dwóch ojców-gejów lub matek-lesbijek. Tak więc pokusa ograbienia tradycyjnej rodziny z jej tożsamości właściwie przestała być już zachętą, a stała się faktem. Ten klimat deprecjonowania klasycznego wzorca rodziny i propagowania rozwiązłości, zaspakajania w sposób nieuporządkowany potrzeb erotycznych, coraz częściej obecny jest w procesie wychowania, nawet jeśli sami rodzice nie do końca zgadzają się i akceptują tego typu pomysły. Jednak, aby nie być posądzonym o nienowoczesność i brak tolerancji, rodzice często milcząco przymykają oczy na zachowania swych dzieci, nie proponując i nie pokazując atrakcyjności innych alternatywnych podejść do życia, miłości i rodziny. Chcąc dać dziecku maksimum wolności de facto dają im maksimum swobody i samowoli, za którymi nigdy nie idzie w parze dojrzałość i odpowiedzialność.

Często owa samowola prowadzi także do zainteresowania się pornografią i prostytucją w sposób czynny. Obydwa te zjawiska, które nachalnie wręcz atakują zewsząd młodego człowieka, mają katastrofalny i nieodwracalny wpływ na jego wnętrze, do tego stopnia, że korzystanie bądź uleganie któremuś z nich, kończy się popełnianiem poważnych przestępstw. Statystyki podają, iż w większości przypadków gwałt i zbrodnia mają swoje źródło w oglądaniu obrazów pornograficznych. Prostytucję także w dużym stopniu wywołuje pornografia, która wyzwala w młodych, nieukształtowanych jeszcze osobach, nieuporządkowany popęd erotyczny, którym młody człowiek nie potrafi sterować. Tymczasem współczesne media w takich formach jak reklamy, filmy, zdjęcia, teledyski, a nawet teksty piosenek przekazują ogromny ładunek erotyczny, kusząc i zachęcając nieprzygotowane umysły i ciała do czerpania z przyjemności fizycznych.

Kolejną pokusą, z którą boryka się wychowanie, jest wspomniana tolerancja. Tolerancja jest kategorią zdecydowanie nadużywaną w usprawiedliwianiu lub wyjaśnianiu rozmaitych kulturowo-społecznych, często po prostu patologicz- 
nych, zjawisk ${ }^{4}$. Jest to słowo-wytrych, przy pomocy którego próbuje się przybliżyć najrozmaitsze fakty i treści, które dotąd uchodziły za społecznie nieakceptowane, wstydliwe lub też należące do sfery zakrytej prywatności. Tymczasem w imię tolerancji twierdzi się, że nie ma żadnej rzeczywistości - tabu, nie ma prywatności, nie ma tajemnicy, gdyż ze wszystkim można obnosić się, wszystko głosić i wszystko obnażać. Dzieci i młodzież, a więc grupa, która była dotąd chroniona przed niektórymi zwulgaryzowanymi aspektami rzeczywistości, stała się nagle pożądanym klientem dla rozmaitych grup „sprzedających” swój nihilistyczny i pozbawiony jakiegokolwiek aksjologicznego fundamentu obraz świata. Obecnie, podpierając się tolerancją, można wszędzie, nawet w szkole, na koloniach, w kółkach zainteresowań, promować ze swadą, bez najmniejszego zażenowania, najrozmaitsze zjawiska, które do tej pory były zarezerwowane dla świata dorosłych. Propozycje, aby w imię swobody seksualnej, rozdawać małoletnim dziewczętom, przebywającym na koloniach letnich, środki antykoncepcyjne, czy też pigułki wczesnoporonne, jest tego przykładem ${ }^{5}$.

Tak zwana tolerancja szerzy się także w kontekście wyglądu młodych ludzi, którzy nie są uczeni cnoty umiarkowania i skromności w tej materii, a raczej zachęcani są do „ekspresji swego wnętrza” poprzez wygląd zewnętrzny, a więc poprzez tatuaże, nieprzyzwoite ubrania odsłaniające ciało, piercing czy bliznowanie. Niektóre z tych "upiększeń" oszpecą młodych na całe życie, ale przecież w chwili obecnej nie należy myśleć o przyszłości, tylko czerpać pełnymi garściami z teraźniejszości. Próby poskromienia gustów promujących nagość, nieprzyzwoitość, wulgaryzm, tandetę kwitowane są skądinąd bałamutnym hasłem stwierdzającym, że mamy prawo wyglądać jak chcemy, choćby nieprzyzwoicie i obscenicznie, i że o "gustach się nie dyskutuje”. Tymczasem o gustach należy i trzeba dyskutować, gdyż nolens volens, zarówno wygląd, podobnie jak i estetyka miejsc, w których się mieszka, zajmuje określoną przestrzeń publiczną, która wpływa na wszystkich uczestników życia społecznego. Wyuzdany wygląd może być dla innych niechcianą przyczyną rozmaitych pokus.

Tolerancja dobrze rozumiana, zgodnie $\mathrm{z}$ jej etymologicznym znaczeniem - z łacińskiego tolerare - „cierpliwie coś znoszę, wytrzymuję”, nie może być jednak utożsamiana $\mathrm{z}$ życzliwą akceptacją nagannych zjawisk, których akceptować nie można. Niestety praxis życia codziennego przynosi zupełnie inne, coraz bardziej rozpowszechnione rozumienie tego terminu, jako całościową aprobatę dla wszystkich postaw i poglądów. Kto nie jest tolerancyjny na modłę

\footnotetext{
4 Por. Wychowanie personalistyczne..., s. 245-252.

5 W „Życiu Warszawy” (z 2 VI 2007) Wanda Nowicka - szefowa „Federacji na rzecz Kobiet i planowania Rodziny" - domaga się, by w czasie letnich kolonii i obozów wychowawcy i lekarze mieli do dyspozycji antykoncepcję postkoitalną. Tymczasem zadaniem wychowawców jest wychowywanie powierzonych im dzieci i młodzieży, a nie ich demoralizacja. Postulat Nowickiej nosi znamiona przestępstwa, gdyż w istocie skłania i aprobuje kontakty seksualne, których regulaminy wszystkich kolonii, zwłaszcza organizowanych dla nieletnich, tego zabraniają.
} 
postmodernistyczną, ten nie jest tolerancyjny wcale. Można nawet stwierdzić, że współczesna kultura chce narzucić nam model tolerancji, który polega na tym, że toleruje się wszystkich, za wyjątkiem tych, którzy czegoś nie chcą tolerować. Taki model tolerancji niestety bardzo chętnie przejmuje młodzież. „Kochajmy się i róbmy co chcemy”, „tolerujmy się" - są to nośne hasła, które prowadzą młodych na etyczne manowce. Hasła tym bardziej niebezpieczne, że często głoszone przez dorosłych, przez autorytety, przez nauczycieli, którzy często sami nie reflektują i nie zgłębiają frazesów proponowanych przez kolorowe pisma, rozrywkowe programy i współczesnych idoli popkultury.

$\mathrm{Z}$ tym fatalnym rozumieniem tolerancji związany jest też relatywizm etycz$n y^{6}$, który jest kolejną pokusą $\mathrm{w}$ wychowaniu, gdyż niszczy same fundamenty wychowania moralnego. Relatywizm moralny odrzuca bowiem istotę moralności, a więc możliwość określenia co jest dobre, a co złe, „oddzielenia ziarna od plew". Uczy, że wszystko jest dobre, wszystko godne wyboru, wszystko powinne moralnie w zależności od sytuacji, w której jestem i od mojego osobistego wyboru podyktowanego okolicznościami, usprawiedliwiającymi ten wybór. Wedle relatywizmu moralnego „cel uświęca środki”. Można wszystko, byleby odpowiadało to tobie, bylebyś był szczęśliwy. Oczywiście szczęście rozumie się w tym kontekście skrajnie indywidualistycznie i egocentrycznie. W relatywizmie pierwsze skrzypce gra moja arbitralna decyzja, mój własny wybór. Owszem, mogę wybrać także dobro, ale wybór ten nie zasadza się na obiektywnym rozróżnianiu dobra i zła, lecz na moim „chcę”, które dziś jest takie, ale jutro może być inne. Ta postawa często wpajana jest wychowankom, gdyż twierdzi się, że współczesny świat wymaga, aby ludzie byli indywidualistami, twardo bronili swoich, choćby najbardziej absurdalnych racji, aby byli silni, pięli się w górę i wydzierali z rzeczywistości to, co dla nich najlepsze, ale niekoniecznie etyczne. Dzieci od najmłodszych lat przygotowuje się do życia, które wymaga odwagi, walki o swoje, o swoją karierę, pozycję, wykształcenie. W takim modelu nie może być miejsca na ofiarę, poświęcenie, uległość, stratę w imię jakichś ideałów etycznych czy religijnych. Takie cechy oznaczałyby jedynie słabość, a tego współczesny świat nie akceptuje. Rodzice i wychowawcy, pragnąc, aby ich dzieci nie zginęły w tłumie silnych, często chcąc nie chcąc, zaszczepiają im relatywizm etyczny, aby było łatwiej im przejść przez życie. Zresztą nierzadko sami wyznają ten pogląd, praktykując go $\mathrm{w}$ pracy i w domu, co samorzutnie wpływa na ich potomstwo.

Częstym argumentem przytaczanym przy okazji relatywizmu moralnego jest kategoria sumienia, którego - co z przewrotną satysfakcją podkreśla się - trzeba bezwzględnie słuchać, bo jak uczy etyka chrześcijańska trzeba „iść za głosem swojego sumienia”. Któż myślący nie zgodzi się z tym nakazem? Jest oczywisty

6 Por. S. Rosik, Wezwania i wybory moralne. Refleksje teologicznomoralne, Lublin 1992, s. 16-17. 
i dobrze osadzony w intelektualnej refleksji. Dlatego też, jak sądzą cynicznie niektórzy, można go użyć jako skutecznego narzędzia, ponieważ doskonale wpisuje się w filozofię relatywizmu etycznego - wybór określonego dla mnie dobra podparty będzie odczytaniem tego dobra we własnym sumieniu. Tymczasem jednak takie myślenie jest nieporozumieniem i nadużyciem moralnym. Zapomina się jakże często, że aby iść za głosem sumienia, trzeba je najpierw dobrze ukształtować, trzeba zadbać o jego należytą formację, trzeba aby sumienie nie stało się studnią bez dna, do której można wrzucić wszystko, lecz aby było autentycznym, działającym bez szwanku, a więc niezepsutym kompasem, który właściwie będzie wyznaczał kierunki, a nie prowadził na manowce. Tak, aby było, jak powiada Arystoteles, sumieniem prawym. Sumienie, które określa się często drogowskazem, kompasem, czy busolą moralną człowieka, nie może wskazywać fałszywych, błędnych kierunków, gdyż człowiek posługując się nim, nigdy nie dotrze do celu, lecz stanie się moralnym nomadem. Aby śmiało iść za sumieniem, trzeba najpierw je dobrze wyregulować, trzeba sprawić, aby stało się prawe. Tymczasem $\mathrm{w}$ procesie wychowania zdarza się zapominać o należytym wyrobieniu sumienia poprzez praktykowanie cnoty roztropności, o zadbaniu o nie, o dostarczaniu mu odpowiedniej dawki wiedzy. Bo wiedza jest niezbędna, aby sumienie dobrze działało i dokonywało właściwych ocen. Sama nazwa łacińska sumienia conscientia - „współwiedza” wskazuje na ten istotny element. Trzeba pamiętać, że z wiedzą łączy się zawsze prawda, a więc coś, co istnieje obiektywnie, a nie czysto subiektywnie w moich osobistych sądach i przekonaniach. Zatem wiązanie sumienia $\mathrm{z}$ relatywizmem etycznym jest $\mathrm{w}$ najlepszym razie czystym nieporozumieniem. Sumienie bowiem nie jest, jak chciał Kant czy Sartre, normą normującą (norma normans), lecz normą normowaną (norma normata), normowaną przez obiektywną rzeczywistość - stąd konieczność zadbania o poznanie owej rzeczywistości i prawdy o niej, konieczność, a wręcz obowiązek poznania prawdy ${ }^{7}$. Często zdarza się, że o wielu zjawiskach nie chce się po prostu do końca wiedzieć, pewnych prawd zgłębić i dopuścić do siebie faktów, które mogłyby zmienić nasze spojrzenie na szereg spraw wokół istniejących. Dzieje się to z prostego powodu: człowiek nie chce wiedzieć, bo musiałby się dostosować, bo zburzyłoby to jego porządek, wygodę i wypracowany status quo. Jakże często na zajęciach $\mathrm{z}$ etyki (na wydziale świeckim) obserwuję wewnętrzne zmagania studentów - katolików, którzy nie chcą dopuścić do siebie określonej wiedzy, gdyż czują, że wytrąci ich ona z moralnego uśpienia, że będą musieli realnie skonfrontować się z nauką Kościoła w wielu kwestiach, że w konsekwencji będą zobligowani zmienić swoje postępowanie, jeśli zechcą samych siebie traktować poważnie. Wygodniej bowiem pozostać przy swojej „prawdzie”, przy sumieniu, które kształtowane jest nakazami „mojego” rozumu, niż poddać się zobowiązującej mocy prawdy i dobra. Człowiek, który lęka się

Por. A. Robaczewski, O cnotach i wychowaniu, Lublin 1999, s. 80-85. 
prawdy i dobra obiektywnego, zawsze chętnie ucieknie do relatywizmu etycznego i permisywizmu moralnego wedle sloganu: „ty masz swoją prawdę, ja mam swoją", pozostańmy więc przy swoich prawdach, których jest tyle, ilu jest ludzi. Logika takiego wywodu prowadzi nie tylko do zatracenia odpowiedzialności osobistej za podjęte działania, do współodpowiedzialności, prowadzi dalej - do anarchii, do naruszenia samych fundamentów życia społecznego, wzajemnego współistnienia ludzi, do zachwiania porządku demokratycznego, prowadzi wprost do nihilizmu. Nihilizm niestety stał się poważnym zagrożeniem współczesnego świata. Filozofia pustki, nicości, absurdu wciąga rzesze młodych ludzi, którzy pozbawieni prawdy uniwersalnej, bo istnieje tylko „moja prawda”, tracą poczucie sensu życia, celu, gubią się w szukaniu pseudocelów i pseudowartości. Ten stan jest obrazem zafałszowanej ludzkiej wolności, opacznie odczytywanej i nadmiernie eksponowanej.

Kolejną pokusą, która rodzi się na gruncie wymienionych zjawisk, jest odejście od Boga i religii, a więc wiara i zaufanie do siebie samego. Twierdzi się, jakże często, że na wiarę i Boga przyjdzie czas, że dziecko jak zechce, to samo wybierze w co, kogo i jak ma wierzyć, że nie można ograniczać dziecka ani straszyć jakimiś normami, grzechami, karami za nie, gdyż dziecko i tak musi zmagać się z wieloma lękami. Ta utrata wrażliwości na Boga, odejście od Niego, rezygnacja $z$ odwoływania się do Jego praw, zanik poczucia Jego obecności nazywa się też sekularyzmem. Zjawisko to dotyka nie tylko niewierzących, ale paradoksalnie także właśnie wierzących, którzy chcą wierzyć, ale „po swojemu”, gdyż nikt (zwłaszcza ksiądz, który nie rozumie życia) nie będzie narzucał czegokolwiek i rozliczał z tego. Człowiek ulega więc pokusie zrównania się z Bogiem, zastąpienia Go, gdyż w centrum wszystkiego zasiada on sam. To zastąpienie teocentryzmu, prymitywnym w swej warstwie intelektualnej, antropocentryzmem niestety ma swoje zgubne skutki indywidualne i społeczne, do tego stopnia, że człowiek zaczyna myśleć, iż może być panem życia i śmierci. Tragiczne, a upowszechniane zjawiska jak aborcja, eutanazja, eutanazja neonatalna, eksperymenty na ludzkich embrionach, postulowanie zrównania praw zwierząt z prawami ludzi, są niestety karygodnymi konsekwencjami zastąpienia Boga. Jeśli Boga nie ma na swoim miejscu, wtedy wszystko inne jest także nie na swoim miejscu - do tego sprowadza się w praktyce sekularyzm. A mówiąc za Fiodorem Dostojewskim: ,jeśli Boga nie ma, to wszystko mi wolno”. Sekularyzm, który odrzuca religijną osnowę podejmowanych decyzji, który polemizuje z normami Bożymi, który kwestionuje sferę duchową, daje człowiekowi złudzenie, że najważniejsze w życiu są dobra materialne, dobrobyt i konsumpcja, i że człowiek w sumie mając kwantum określonych dóbr jest w gruncie rzeczy samowystarczalny.

Jeśli już jednak potrzebuje nieco oderwania się od luksusu, to zawsze może zafundować sobie namiastki duchowości w rozmaitych sektach i związkach 
religijnych. Te formy pseudoduchowości, odpowiednio wcześnie nierozpoznane przez rodziców, nie tylko niszczą więzi rodzinne, społeczne, ale rujnują psychikę młodego człowieka, która często jest nie do odbudowania.

Sygnalizowane zagrożenia - pokusy, które pojawiają się na gruncie wychowania, nie są niestety jedynymi. Współczesny świat, który bombarduje zewsząd wieloma treściami kultury masowej, pod pozorem troski i pomocy wychowawcom i rodzicom w procesie wychowawczym, przekazuje niestety fałszywe prawdy, proponuje złudne cele i niegodziwe środki. Zalew tanich kolorowych pisemek, łatwość dotarcia do treści erotycznych, błędne rozumienie przedmiotu wychowania w rodzinie, rozprzężenie moralne dorosłych, którzy przestają być autorytetami, promowanie książek, naukowców, wykładowców, którzy propagują liberalny punkt widzenia norm moralnych, brak systematycznych zajęć z etyki dla przyszłych pedagogów, to wszystko sprawia, że „wychowanie bez porażek", które zamierzali zrealizować propagatorzy liberalizmu wychowawczego, kończy się jakże często „porażką wychowania”. A kultura pokus, która dominuje w postmodernistycznej rzeczywistości, powoli przechodzi z fazy zachęty do fazy realizacji, prowadzącej do wychowawczego nihilizmu, aksjologicznej pustki i moralnej pustyni. 